\title{
Paideusis
}

\section{"Michel Foucault: Materialism and Education" (Mark Olssen) Jeff Stickney}

Volume 16, Number 1, 2007

URI: https://id.erudit.org/iderudit/1072611ar

DOI: https://doi.org/10.7202/1072611ar

See table of contents

Publisher(s)

Canadian Philosophy of Education Society

ISSN

0838-4517 (print)

1916-0348 (digital)

Explore this journal

Cite this review

Stickney, J. (2007). Review of ["Michel Foucault: Materialism and Education"

(Mark Olssen)]. Paideusis, 16(1), 73-78. https://doi.org/10.7202/1072611ar viewed online.

https://apropos.erudit.org/en/users/policy-on-use/ 
Review of

\title{
Michel Foucault: Materialism and Education
}

\author{
by Mark Olssen, Boulder, CO: Paradigm Publishers, 2006, Updated Edition
}

JEFF STICKNEY
OISE/University of Toronto, Canada

Mark Olssen's recently re-issued book deserves a second look, especially from those like me who gave the earlier version only a selective, less judicious read. Do not be deterred by the title: this is no reductive account. Olssen avoids forcing Foucault into the mould of classical Marxism, with its reification of economic substratum and super-structural elements. In describing Foucault as a "historical materialist," he meticulously explains how Foucault moved away from traditional, mechanical, and dialectical brands, demonstrating why Foucault scholars such as Hubert Dreyfus and Paul Rabinow, Arnold Davidson and Ian Hacking, and even Foucault himself give some credence to the label of "materialist." Defence of this position makes an original entry point into Foucault's philosophy and its relevance to education.

The book is most deserving of the praise given on its jacket by Michael Peters, Henry Giroux, and James Marshall, and it would be an audacious move to go against their strong recommendations. Fortunately, there is no reason to perform a dashing "power reversal." Despite some potential areas of contention, which I will highlight, I feel certain that Foucault scholars will generally agree with and appreciate Olssen's work.

In the role of critic, I want to retain an ethical, asymmetrical stance that respects the enormous work behind Olssen's achievement, at best working alongside his project instead of strategically leveraging my own project off his. Let me elaborate on his project and its merits and then perform the task of offering useful criticism as well as confirmation. ${ }^{1}$

The book is commendable both as a reference guide to Foucault and for its pedagogic value as exemplary scholarship and writing. Throughout the text, Olssen combines erudition with lucidity. His writing is generous to those entering the field of Foucault scholarship without tiring those more familiar. The design builds a coherent case throughout, facilitating ease of uptake through wellportioned sections. He clearly and carefully weighs contending interpretations before offering his own stance, allowing readers the opportunity to engage in a critical conversation with the author and with Foucault's texts. Conclusions are often suggestive instead of didactic, inviting us to form meaning. To his credit, Olssen heeds Colin Gordon's advice by not giving a glorified account of Foucault. ${ }^{2}$ There is, instead, a search for how the contributions of other thinkers might support Foucaultian research in education.

With an ultimate political goal of helping educationists to constitute "a new subject of democracy" (p. xi), the book is divided into three sections: "The Modified Realism of Michel Foucault"; "Considering Foucault as Historical Materialist"; and, "Foucault and the Tasks of Education." The first section sets out Foucault's methods and surveys key concepts such as power/knowledge and the constitution of the subject. Olssen delivers a coherent synopsis of Foucault's corpus, without imposing a theory that would go against Foucault's warnings about looking

(C) Copyright 2007. The author, Jeff Stickney, assigns to Paideusis the right of first publication and educational and non-profit institutions a non-exclusive license to use this document for personal use and in courses of instruction provided that the article is used in full and this copyright statement is reproduced. Any other usage is probibited without the express permission of the author. 
for unified authors and works (oveures). ${ }^{3}$ He traces diverse influences on Foucault, from Sartre and Althusser to Heidegger, Nietzsche, and Spinoza, without suggesting an easy, explanatory account.

The second section of the book takes up the question of what unifies Foucault's work and what sets him apart from other linguistic philosophers such as Derrida and Lyotard (Chapter 5). Here Olssen builds upon the distinction between the "discursive" and "extra-discursive" through a materialist lens, which I question later. This section usefully sets up the discussion of Critical Theory in the third section, exploring Foucault's relation to Hegel, Marx, and Gramsci, and delivering a cogent, materialist defence against charges of "judgmental relativism" while making concessions to "epistemic relativism" (Chapter 6).

The third section, which contains the most significant revisions, explores the relevance to education. Olssen first positions Foucault in relation to Kant, the Enlightenment, and Habermas' criticisms, and then moves to "Educating the Self," with a consideration of the materiality of technologies of self-transformation. "Foucault's Influence on Educational Research," updated, provides an especially useful review of the literature. Here, Olssen assays research on Foucault's influence on educational psychology (e.g., Nikolas Rose), genealogies of education reforms (e.g., Ian Hunter), and problematizations of "autonomy" and neo-liberal forms of governmentality in education (e.g., Michael Peters and James Marshall).

The final chapter, substantially rewritten to reflect Olssen's thoughts on Foucault and agency, offers a culmination of the earlier themes - "Freedom, Materialism, Politics, Ethics." Whereas the first edition of Olssen's book inspired me to renew my reading of Gramsci in relation to the writings of Foucault, without reducing one to the other, the second takes us further into a reconsideration of the positive sense in which Foucault offers a politics of liberation. Foucaultians will want to explore with Olssen how we might broaden prospects for political action - beyond the micro realm of "care of the self" and local governance - at the level of state jurisdictions, which so often set educational policy. ${ }^{4}$ In his original, though controversial, thesis of "minimal universalism" in Foucault (p. 209), Olssen now claims that Foucault's politics of difference also entail a sense of unity, giving us a normative approach to democratic politics perhaps better than Rorty's (p. 212). The thesis that Foucault tacitly advances certain principles of power equalization and reversal of domination, or ranges of freedom within rules and given social conditions, deserves more attention, even among those who might suspect Olssen is reading Freire's democratic politics of emancipation into Foucault. Much as Foucault remarked on his relation to Nietzsche, Olssen's project is less about getting Foucault definitively 'right' than about using his philosophy productively in education research and activism. ${ }^{5}$

Think of Olssen's significant project this way, drawing on Foucault's notion of power circulating instead of residing in persons or the sovereign. If the modern university could be, perhaps too gloriously, considered a particle accelerator (say, CERN), then Olssen is a physicist who watches the annihilation event of historical-materialism. His meticulous work traces the explosion of that philosophical discourse, following its elemental particles floating in the different trajectories of such contemporary thinkers as Deleuze, Foucault, Laclau, and Mouffe. Indeed, Olssen once qualifies the moniker "materialism" by referring to Foucault as giving a "microscopic" form of historical materialism (p. 137), and he closes his book with a well-qualified defence of this descriptor, in that Foucault continues in this philosophic tradition (p. 206). "Microscopic," one might say, because Foucault is concerned with how people as subjects - of rules, power/knowledge complexes, modes of governance, and regimes of truth - are, in Foucault's words, "gradually, progressively, really and materially constituted through a multiplicity of organisms, forces, energies, materials, desires, thoughts, etc."6

Let me turn now to constructive criticism. Analogies, of course, bring their own dangers. Some readers may find Olssen's discussion of emergent properties within chaos theory to be going too far in the direction of suggesting a material basis (p. 200), even though he carefully notes (nt.3, p. 217) that such extensions into physics are largely for illustrative purposes (i.e., "parallels and affinities"). He is not trying, like Empedocles, to explain free will in a deterministic universe through swerving atoms, but applying a range of post-Einstein, field-theory (holistic and particularistic, and even stochastic) 
materialist discourses to the fields of psychology, economics, and education. His discussion of individuation and creativity, and limited freedoms within constitutive discourses and non-discursive practices, offers an original and thought-provoking treatment of the topic. Olssen responds to critics like Christopher Norris who claim that Foucault does not allow ethical space for degrees of agency, and to those who would argue that there is no basis for politics in Foucault's writing (p. 195).

As suggested at the outset, attribution of "historical materialism" to Foucault's philosophy requires considerable qualification, inviting the question as to why Olssen chose this contentious moniker and whether it is essential to his political project. Does the title create what Wittgenstein called "a tête-á-tête with himself"? ${ }^{7}$ Although nobody would contest the attribution of "historical" to Foucault's work (e.g., a "historical ontology of the present"), the label "historical-materialist" suggests to many a materialist of a particular kind. ${ }^{8}$ In retaining the name he now wants us to apply differently, Olssen entangles himself somewhat needlessly in the dichotomy between nominalism and realism he so cogently describes in relation to Foucault (Chapter 5). In other words, he is rather nominalist in his attribution of "historical materialism," even though he marshals a consensus of Foucault scholars in defence of his claim that Foucault has a "materialist" leaning (pp. 56-7). Olssen's deconstruction and reconstruction of "historical materialism" has an agenda, tied to clearing Foucault of false accusations of being a "relativist" and a "postmodernist" in the same camp as Derrida and Lyotard. These postmodernists are associated with hyper-valuation or fetishization of textuality, and an overblown "incredulity to all meta-narratives" 9 that leaves them more susceptible to accusations of relativism. Materialism - with its historical contingency redefined through the lineage of Kant, Hegel, Nietzsche, Spinoza, and Heidegger - becomes the avenue for defending Foucault from the pejorative senses of being merely a "nominalist," "constructivist," and "postmodernist."

Expressed in terms of the arguments between nominalism and materialism, the case Olssen makes adheres more closely to the dualism between linguistic-idealism and realism. Although he is careful not to place Foucault at either end of this dualism, to some extent he is driven by the far-flung accusations of critics like Norris: authors who proclaim themselves to be the voice of rationality while employing many of the same rhetorical devices of those "rhapsodists" they criticize. In philosophy of education, the voices of Harvey Siegel and D.C. Phillips, though tempered by politeness toward their feminist and postmodernist opponents, have similar performative force in proclaiming themselves rational and their adversaries nearly insane. ${ }^{10}$ This kind of academic climate forces Olssen to dig deeply for the realist undertones in Foucault to show that neither he nor reasonable Foucaultians actually deny, with self-refuting certainty, the prior existence of the world. ${ }^{11}$ Foucault is adamant that by "problematization" he does not mean to suggest that what becomes "produced," and therefore problematic, through veridical discourse is not somehow real. ${ }^{12}$

In contending with 'realist' critics like Norris, there is the danger of adopting some of their terminology: this has possibly occurred in the case of Olssen's use of the term "extra-discursive" for what ordinarily translates as "non-discursive" practices. ${ }^{13}$ Norris wrote a section entitled "Of Reality and Truth in an Extra-Discursive Sense," apparently mocking Nietzsche's title from the early notebooks: "On the Truth and Lies in a Nonmoral Sense."14 Olssen tries to leverage an "extradiscursive" aspect of Foucault's work against Derrida and Lyotard's anti-realist privileging of discourse (p. 48), and against Laclau and Mouffe's critical approach that rejects the distinction between discursive and non-discursive (p. 114). I think here, in turning critic, Olssen grasps for something more solid that is not there in Foucault, as he elsewhere shows. Olssen's materialist critique of postmodernism is the least convincing aspect of an otherwise fine book.

At the risk of leaving the reader behind in an argument with myself, let me elaborate on this tension and point to its resolution. In light of Foucault's debt to Heidegger, we might say that nothing is "extra-linguistic" or unmediated in the sense that beings come to be present in language (the House of Being). Although Olssen alludes to Heidegger earlier as a profound influence on Foucault (p. 4), Heidegger could have come into play alongside Marx in the early discussion of Foucault's nominalism and constructivism (in Chapter 5, as well as later, in pp. 141-43). In other words, instead of 
highlighting the materialist side of Foucault, one could also argue that it was an underlying but subtle realist ontology of "coming to be present" (in discourse) that was articulated in Foucault's notions of the production and problematization of truths within discourses, regimes of truth, and power relations, as Olssen suggests in his conclusion (p. 212). ${ }^{15}$

As a corrective to an emphasis on materialism, one could go further with Carlos Prado in attesting to the primacy of discourse over matter in Foucault's nod to realism in his early work. Anything material is almost inconsequential - which is different from saying it is non-existent or not real after all - one might say, to the real task, the Nietzschean and Heideggerian question of the historical ontology of truths and falsehoods. Prado rightly shows that although Foucault is a tacit realist, he is not so much concerned with this materiality behind truth. In The Archaeology of Knowledge, Foucault states that he is not interested in "interpreting discourse with a view to writing a history of the referent." I cite this passage not as criticism of Olssen, but as a caution to his readers. Olssen cites it himself (p. 43-44) and correctly explains that, "our engagement with the world is always mediated by discourse which is constituted by 'relations'...” (p. 44). Foucault says:

What, in short, we wish to do is to dispense with 'things'. To 'depresentify' them. ...To substitute for the enigmatic treasure of 'things' anterior to discourse, the regular formation of objects that emerge only in discourse. ${ }^{16}$

Following Prado's argument (and indeed that of Olssen, on p. 44), let me go further to show how adamant Foucault was about this separation from things:

I would like to show with precise examples that in analysing discourses themselves, one sees the loosening of the embrace, apparently so tight, of words and things, and the emergence of a group of rules proper to discursive practice. ${ }^{17}$

Foucault makes it clear he is not returning to semiotics or structuralism, in that he is not "treating discourse as groups of signs... but as practices that systematically form the objects of which they speak." 18

The reading Hacking gives to this movement of thought in his landmark essay "Making Up People" is closer to the Wittgensteinian sense of rule-governed behaviour, or as Elizabeth Anscombe put it, a view of intentional actions or practices being "under a description." 19 Instead of playing up the "extra-discursive," Foucault's discussion of "non-discursive practices" (such as dividing practices: sorting the 'sane' and 'insane') always have the discursive element already entailed within them. When not critiquing the postmoderns, Olssen explains that for Foucault, material cannot be apprehended outside of discourse (e.g., via empiricist-realism or reductive and eliminative materialism, p. 202), as "the non-discursive is mediated by discourse" (p. 207). Language cuts across, or is entangled in, the non-discursive. In this sense, non-discursive practices are rather like Wittgenstein's language-games.

Olssen is keenly aware of these connections to Wittgenstein and brings them into his conversation (p. 55, p. 199). The revised text could further explore the parallels between Wittgenstein's nominalist discussion of rules, in which words do not connect with things outside of the grammar of their usage, like "wheels that do not turn anything," and Foucault's discussion of how subjects stand in relation to rules in his fourfold of subjectivization. ${ }^{20}$ Foucault explores four components of this problematic: ethical substance, the aspect of the self that one alters; ethical work, the means by which one transforms oneself; telos, the aim of the ethical subject given its circumstances; mode of subjectification or self-stylization and form-giving. The latter he explains as follows: "The way in which the individual establishes his relation to the rule and recognizes himself as obligated to put it into practice." 21 If one stands at the particle accelerator I referred to earlier, one is apt to emphasize "ethical substance" as a corrective to those who have wrongly criticized Foucault for being a "linguistic idealist" (e.g., Habermas and Norris). The danger is then to proclaim him a "materialist," which plays 
into a longstanding dividing practice that has been historically constructed through philosophical discourse. It is, in Hacking's words, one way we "make up people," but then so much effort has to go toward qualifying that loaded name. Foucault, and perhaps Olssen, would likely have been in sympathy with Wittgenstein's remark that the differences between realist and idealist amount to "battle cries." 22 The question is how they would raise their children within these discourses of the true and false, and whether they would practice different regimes of discipline, governance, and training in the normalization of their children. ${ }^{23}$

Olssen initiates this kind of discussion in relation to Wittgenstein and Bourdeiu (babitus), noting how Foucault accounts for originality among similarly constituted selves: "Foucault is interested in explaining how infinite possibilities of application arise from a limited number of rules that constitute the social conditions of existence" (p. 198). From these kinds of emergent digressions within ranges of possibility or limited conditions (p. 203), we get a sense of how, instead of freedom being a "Kantian birthright" (rational autonomy), "The human subject is socially and historically constituted and develops a capacity for freedom and decision-making slowly, progressively, heteronomously, and with different success. Freedom is a political skill or power to be exercised" (p. 206).

The book is commendable for showing the historical and material aspects of these kinds of transformative and politically charged practices of freedom in education. Instead of reducing these to singular economic and materialist explanations, Olssen shows that Foucault's "approach stresses multiplicity of material causes, as well as the constitutive role of discourse. Against liberals he displaces the ontological priority placed on the individual as the author of his or her own self and moral individualism that such an approach entails" (p. 192). Whether this commits us to consider Foucault as a "thin communitarian" (p. 212) is something I leave the reader to investigate. Like an exhilarating conference, Olssen's book draws the reader into this conversation with a feeling of social-democratic purpose behind the academic questions. I advise readers to attend to this important book.

\section{Endnotes}

\footnotetext{
${ }^{1}$ Remember, Foucault's concept of the "political production of truth" is not the same as the Marxist critique of ideology, in which one proclaims the false consciousness of an ideology to stand corrected by some more real version of what counts as the truth. See Michel Foucault, "Truth and Power," in Power/Knowledge, ed. Colin Gordon (New York: Pantheon Books, 1980), p. 118.

2 Colin Gordon, "Introduction," on hagiography, in Foucault's Essential Works, Vol. 3, ed. James Faubion (New York: The Free Press, 1994), p. xiii.

3 See Michel Foucault, The Archaeology of Knowledge, trans. A. M. Sheridan Smith (London and New York: Routledge, 2002), p. 25.

${ }^{4}$ See Olssen, pp. 107-108, for Foucault's evasive response to this topic in a 1978 interview. See also The Antonio Gramsci Reader. Selected Writings 1916-1935, ed. David Forgacs (New York: New York University Press, 2000).

${ }_{5}$ Michel Foucault, "Prison Talk," in Colin Gordon, ed. Power/ Knowledge, Selected Interviews \& Other Writings, 1972-1977 (New York: Pantheon Books, 1980), pp. 53-54.

${ }^{6}$ Michel Foucault, "Two Lectures," in Colin Gordon, ed. Power/ Knowledge, Selected Interviews \& Other Writings, 1972-1977 (New York: Pantheon Books, 1980), p. 97.

${ }^{7}$ Ludwig Wittgenstein, Culture and Value, ed. G.H. von Wright with Heikii Nyman; trans. Peter Winch (Oxford: Basil Blackwell, 1980), p. 77e. "Nearly all my writings are private conversations with myself. Things that I say to myself tête-á-tête."

${ }^{8}$ Michel Foucault, "What is Enlightenment?" In Essential Works, Vol. 1, ed. Paul Rabinow (New York: The Free Press, 1994).

9 Jean Francois Lyotard, The Postmodern Condition: A Report on Knowledge, trans. Geoff Bennington and Brian Massumi; foreword by Fredric Jameson (Minneapolis: University of Minnesota Press, 1984).

${ }^{10}$ See Harvey Siegel, "Knowledge, Truth and Education," Chapter 1 in David Carr (ed.), Truth, Knowledge and Education (London: Routledge, 2000).
} 
${ }^{11}$ See Michel Foucault, "The Ethics of the Concern for the Self as a Practice of Freedom," in Essential Works, Vol. 1, ed. Paul Rabinow (New York: The New Press, 1994), p. 296.

12 See Michel Foucault, Fearless Speech, ed. Joseph Pearson (Semiotext(e), 2001), p. 171.

${ }^{13}$ See Olssen, pp. 44-45, pp. 57-58, pp. 63-64, p. 73, pp. 113-4, p. 138.

14 See Christopher Norris, Reclaiming Truth. Contribution to a Critique of Cultural Relativism (London: Lawrence and Wishart, 1996), Ch.4, VI, p. 167. See Friedrich Nietzsche, Philosopby and Truth. Selections from Nietzsche's Notebooks of the early 1870's, ed. and trans. Daniel Breazealle (Amherst, New York: Humanity Books, 1999), Ch. IV, p. 79.

15 See Michel Foucault on the connection between reality and truth in problematization, as being opposed to "historical idealism" (i.e., as pertaining to "real existents in the world" and to history), in Fearless Speech, ed. Joseph Pearson (Los Angeles: Semiotext(e), 2001), pp. 171-2.

16 Foucault, The Archaeology of Knowledge, 52-53. See Carlos Prado, Searle and Foucault on Truth (Cambridge: Cambridge University Press, 2006), p. 162.

${ }^{17}$ Foucault, The Archaeology of Knowledge, p. 54.

${ }_{18}$ Foucault, The Archaeology of Knowledge, p. 54.

19 G.E.M. Anscombe, Intention (Oxford: Blackwell, 1957), cited in Ian Hacking, "Making Up People," in T.C. Heller et. al. (eds.), Resconstructing Individualism (Stanford, CA: Stanford University Press, 1986), p. 230.

${ }^{20}$ Ludwig Wittgenstein, Philosophical Investigations, 3d edition, trans. G.E.M. Anscombe. (Oxford: Basil Blackwell, 1968), \271. See Mark Olssen, "Wittgenstein and Foucault: The limits and possibilities of constructivism," Access: Critical Perspectives on Education Policy, 13 (2), Special Issue: Constructivism in Science Education (pp.71-78). James Marshall inaugurated this comparison in philosophy of education, with "Wittgenstein on Rules: implications for authority and discipline in education," Journal of Philosophy of Education, 19, no. 1 (1985): pp. 3-11. See also by Marshall, "Wittgenstein and Foucault: Resolving Philosophical Puzzles," in Philosophy and Education: Accepting Wittgenstein's Challenge, eds. James Marshall and Paul Smeyers (Dordrecht, Boston and London: Kluwer Academic Publishers, 1995).

${ }^{21}$ See Michel Foucault, History of Sexuality, Vol. 2 (New York: Random House, Vintage Books Edition, 1990), pp. 26-28. Extracting each mode from a sentence, on p. 26, p. 27, p. 27, and p. 28, Paul Rabinow refers to these as Foucault's “ethical fourfold." See his "Introduction," Essential Works, Vol.1 (New York: The New Press, 1994), p. xxxiii.

${ }^{22}$ Ludwig Wittgenstein, Remarks on the Philosophy of Psychology, ed. G.E.M. Anscombe; trans. G.H. von Wright (Oxford: Basil Blackwell, 1980). Vol. II, §338.

${ }^{23}$ Ludwig Wittgenstein, Zettel, trans. G.E.M. Anscombe (Oxford: Basil Blackwell, 1967), §414. 